\title{
REDUCED RESPONSIVENESS OF ADENYLATE CYCLASE TO FORSKOLIN IN HUMAN LYMPHOMA CELLS
}

\author{
Michael Hallek, ${ }^{*}+$ Torsten Kamp, ${ }^{*}$ Ekkehard Haen, + Ursula Göly, ${ }^{*}$ \\ BERTOLD EMMERICH ${ }^{*}$ and JÖRO REMIEN + \\ * Medizinische Klinik, Klinikum Innenstadt, and $\$$ Walther Straub-Institut für Pharmakologie und \\ Toxikologie, University of Munich, Germany
}

(Received 17 April 1990; accepted 20 April 1991)

\begin{abstract}
The $\beta_{2}$-adrenergic transmembrane signal transduction was investigated in malignant B-cells from 15 patients with low grade non-Hodgkin's lymphoma as compared with normal lymphocytes of seven healthy adults. The number of $\beta_{2}$-adrenoceptors and the response of adenylate cyclase (AC) to isoproterenol were slightly decreased in lymphoma cells. The responsiveness of AC to forskolin was 8fold lower in lymphoma cells, whereas the response to cholera toxin showed no difference. These findings demonstrate an impairment of the $\beta_{2}$-adrenergic signal transduction in low grade lymphoma cells that particularly affects the function of $\mathrm{AC}$. The comparison with forskolin resistant mutants of an adrenocortical tumor cell line, Y1 (Schimmer et al. J Biol Chem 262: 15521-15526, 1987), suggests that the availability of functional active alpha subunits of stimulatory $G$ proteins $\left(G_{s}\right)$ might be reduced in human B-cell lymphoma, although other mechanisms known to inhibit the $A C$ activity might be involved.
\end{abstract}

Normal human lymphocytes bear $\beta_{2}$-adrenergic binding sites [1], whose interaction with catecholamines results in the stimulation of the enzyme adenylate cyclase $(\mathrm{AC} \$)$ via the stimulating GTP binding protein $\left(G_{s}\right)[2]$, thereby increasing the intracellular concentration of cyclic $3^{\prime}: 5^{\prime}$-adenosine monophosphate (cAMP). This second messenger seems to inhibit most functions of mature human lymphocytes including mitogen-induced DNA synthesis $[3,4]$, anaerobic glycolysis [5], production of lymphokines [6] and antibodies [7], T-cell mediated cytolysis [8-10] and motility of T- and B-cells [11]. However, cAMP has been found to enhance the differentiation of both immature lymphocytes [12] and lymphoma cells [13]. The plasma, urine and intracellular cAMP levels were reported to be decreased in patients with acute (ALL) and chronic lymphocytic leukemia (CLL) [14-17]. Both adrenergic binding sites and the stimulation of $\mathrm{AC}$ by catecholamines were shown to be reduced in CLL lymphocytes [18-21]. Recently, the adenylate cyclase system has received increasing attention because of its possible role in malignant transformation [22-29]

† Address for correspondence: Dr Michael Hallek, Dana-Farber Cancer Institute, Harvard Medical School, 44 Binney Street, Boston, MA 02115, U.S.A.

$\$$ Abbreviations: $A C$, adenylate cyclase; $G_{s}$, stimulatory GTP binding protein; $G_{i}$, inhibitory $G T P$ binding protein; cAMP, cyclic $3^{\prime}: 5^{\prime}$-adenosine monophosphate; DNA, deoxyribonucleic acid; ALL, acute lymphoblastic leukemia; CLL, chronic lymphocytic leukemia; IC, immunocytoma; cccb, centrocytic-centroblastic; $\mathrm{HH}$, Hepes buffered Hank's salt solution; IBMX, 3-isobutyl-1-methylxanthine; ${ }^{125}$ ICYP, ${ }^{125}$ iodo-cyanopindolol; MNL, mononuclear leucocytes; TB, total binding; UB, unspecific binding; $K_{d}$, dissociation constant; $\mathrm{NaF}$, sodium fluoride, $\mathrm{Gpp}(\mathrm{NH}) \mathrm{p}$, guanyl-5t $-y 1$ imidophosphate; ACTH, adrenocorticotropic hormone.
cAMP was demonstrated to suppress neoplastic Bcell proliferation in human and murine lymphoma cell lines $[30,31]$. We therefore conducted a study to determine the number and affinity of $\beta_{2}$ adrenoceptors on normal and malignant human lymphocytes and to investigate the function of the $\beta_{5}$-adrenergic signal transduction (receptor, $\mathrm{G}_{5}, \mathrm{AC}$ ) in these cells by stimulation with different agents (isoproterenol, cholera toxin and forskolin).

\section{MATERIALS AND METHODS}

Patients. Fifteen patients with leukemic low grade non-Hodgkin lymphoma (lymphocyte count $>10^{4}$ cells $/ \mu \mathrm{L}$ ) aged from 48 to 79 years (median 68 years; mean \pm SD $63.5 \pm 10.5$ years; seven female eight male) treated in the Medizinische Klinik, Klinikum Innenstadt, Munich, Germany, entered the study. Six apparently healthy subjects and one patient with coronary heart disease without further complications or treatment, aged from 24 to 78 years (median 33; mean \pm SD $42.8 \pm 20.7$; two female, 5 male) served as controls. The histopathological entities according to the Kiel classification [32] were distributed as follows: $12 \mathrm{CLL}$, two immunocytoma (IC) and one centrocytic-centroblastic lymphoma (cccb). Immunophenotyping of mononuclear leucocytes (MNL) in patients showed that all were Bcell lymphoma, and that more than $90 \%$ of MNL were B-cells. CLL and IC patients were staged according to the Binet classification [33], the cccb patient according to the Ann Arbor classification [34]. Three of the $14 \mathrm{CLL}$ and IC patients were in Binet stage $A$, six in stage $B$ and five in stage $C$. The cccb patient was in stage IV. No patient received chemotherapy or took sympatholytic or sympathomimetic drugs.

Materials. Hepes buffered Hank's salt solution (HH) consisted of the following compounds diluted 
in distilled water: $1.26 \mathrm{mmol} / \mathrm{L} \mathrm{CaCl}, 5.4 \mathrm{mmol} / \mathrm{L}$ $\mathrm{KCl}, 0.44 \mathrm{mmol} / \mathrm{L} \mathrm{KH}_{2} \mathrm{PO}_{4}, 0.8 \mathrm{mmol} / \mathrm{L}, \mathrm{MgSO}_{4}$, $136.9 \mathrm{mmol} / \mathrm{L} \mathrm{NaCl}, 0.42 \mathrm{mmol} / \mathrm{L} \quad \mathrm{Na}_{2} \mathrm{HPO}_{4}$ (all salts purchased in analytical purity from Merck, Darmstadt, Germany), and $25.0 \mathrm{mmol} / \mathrm{L}$ Hepes (Sigma Chemical Co., St Louis, MO, U.S.A.). This buffer was adjusted to $\mathrm{pH} 7.4$ with $1 \mathrm{~N} \mathrm{NaOH}$ solution. Forskolin, cholera toxin (vials of $1 \mathrm{mg}$ lyophilized protein), 3-isobutyl-1-methylxanthine (IBMX) and (-)isoproterenol bitartrate were purchased from Sigma, $(-)^{125}$ iodo-cyanopindolol ( ${ }^{125} \mathrm{ICYP}: \quad 2000 \mu \mathrm{Ci} / \mathrm{mmol}$ ) from Amersham (Braunschweig, Germany), and heparin from Novo Industrie (Mainz, Germany). (-)Timolol maleate was a generous gift from Merck Sharp and Dohme (Munich, Germany)

Binding assay. The experimental procedure was performed as described previously [35]. with small modifications. Briefly, samples of $15-20 \mathrm{~mL}$ heparinized, venous blood were obtained between 9 and 10 a.m. MNL were harvested by density gradient centrifugation [36]. The MNL fraction was washed twice in $\mathrm{HH} \mathrm{pH} 7.4$ and then resuspended in this buffer. Intact cells $\left(5 \times 10^{5}\right)$ were incubated in $100 \mu \mathrm{L}$ with varying concentrations $(1.0-180 \mathrm{pmol} /$ L) of ${ }^{125} \mathrm{ICYP}$ for $120 \mathrm{~min}$ at $37^{\circ}$ to determine total binding (TB). Unspecific binding (UB) was determined in parallel incubations with $1 \mu \mathrm{mol} / \mathrm{L}$ unlabelled $(-)$ timolol. Specific binding was defined as TB - UB. After the incubation period, the samples were centrifuged at $15,000 \mathrm{~g}$ for $5 \mathrm{~min}$ and the supernatant was removed by suction. The pellets were counted in a Packard Gamma Spectrometer (model 5360).

Specific binding data were iteratively fitted by non-linear regression analysis to a model of two independent binding sites as described earlier $[35,37]$, using the Enzfitter program from Biosoft ${ }^{\circledR}$, Cambridge, IJ.K. This model was used hecause previous studies in our own laboratory, as well as in other laboratories, suggested the existence of two rather than one hinding site for $\beta_{2}$-adrenoceptors on human MNL $[35,37,38]$. Binding data were also plotted according to the method of Scatchard [39] in order to visualize results. Since the functional and molecular properties of the low affinity binding site are yet to be defined, only the results for the high affinity binding site were considered, and the high affinity binding site was called $\beta_{2}$-adrenoceptor. $K_{d}$ and $B_{\max }$ represented the equilibrium dissociation constant and density of the high affinity binding site in the saturation experiments.

Stimulation of $A C$ and $C A M P$ assay. MNL $\left(5 \times 10^{5}\right.$ in $500 \mu \mathrm{I}$.) were preincubated for $30 \mathrm{~min}$ at $20^{\circ}$ in the presence of $10^{-3} \mathrm{~mol} / \mathrm{L}$ IBMX to inhibit phosphodiesterase activity. Thereafter, the cells were incubated at $37^{\circ}$ with isoproterenol $\left(0,10^{-8}\right.$. $5 \times 10^{-7}$ and $10^{-4} \mathrm{~mol} / \mathrm{L}$ ) for $10 \mathrm{~min}$, cholera toxin $\left(0,10^{-6}\right.$ and $\left.10^{-4} \mathrm{~g} / \mathrm{mL}\right)$ for 60 or $120 \mathrm{~min}$, or forskolin $\left(10^{-4} \mathrm{~mol} / \mathrm{L}\right)$ for $15 \mathrm{~min}$. Isoproterenol was diluted in $\mathrm{HH}$ buffer, cholera toxin in distilled water, and forskolin in $100 \%$ ethanol (control experiments with ethanol revealed no influence on cAMP accumulation). The reaction was stopped by incubating the cells at $100^{\circ}$ for $5 \mathrm{~min}$. Thereafter, the cells were centrifuged at $15,000 \mathrm{~g}, 300 \mu \mathrm{L}$ of the
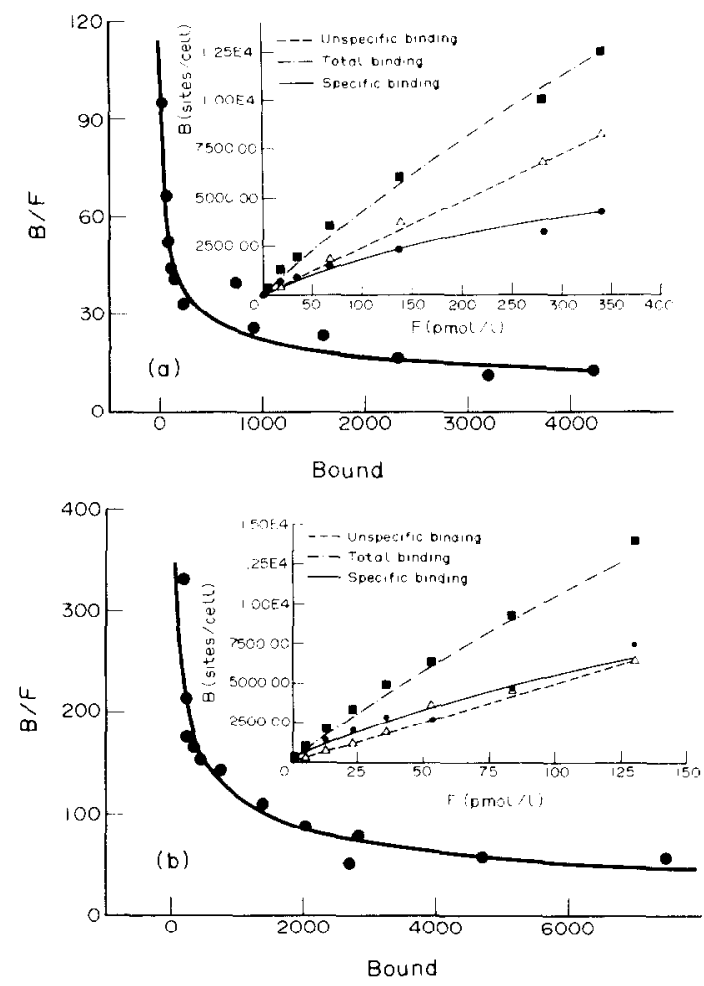

Fig. 1. (a) Binding curves and Scatchard plot of a saturation experiment with ${ }^{225}$ ICYP and intact lymphocytes of a healthy male adult ( 78 years old). The binding parameters for the high affinity binding site obtained by non-linear regression analysis were: $B_{\max }=455.8$ sites $/$ cell, $K_{d}-$ $1.8 \mathrm{pmol} / \mathrm{L}$. (b) Binding curves and Scatchard plot of a saturation experiment with ${ }^{125}$ ICYP and intact lymphocytes of a female CILL patient, Binet stage A ( 75 years old). The binding parameters for the high affinity binding site obtained by non-linear regression analysis were: $B_{\max }=$ 74.8 sites $/ \mathrm{cell}, K_{d}=0.6 \mathrm{pmol} / \mathrm{L}$.

supernatant were removed and stored at $-30^{\circ}$, until the cAMP content was determined in duplicate with a $\left[{ }^{125} \mathrm{l}\right] \mathrm{cAMP}$ radioimmunoassay kit of Amersham Braunschweig, Germany [40].

Statistics. Patients and controls were compared by the Mann-Whitney test for independent samples. A $P$ value $<0.05$ was regarded as statistically significant. All results are given as mean \pm SEM.

\section{RESULTS}

$\beta_{2}$-Adrenoceptors in normal lymphocytes and lymphoma cells

Representative experiments of ${ }^{125} \mathrm{ICY}$ P binding to intact MNL are shown in Fig. $1 \mathrm{a}$ and $b$. The number of high affinity ${ }^{125} \mathrm{ICYP}$ binding sites $\left(\beta_{2}-\right.$ adrenoceptors) per cell was 455.8 in MNL of a 74 year-old healthy person (Fig. 1a) and 74.8 in MNL of a 75-year-old CLL patient (Fig. 1b). As a group phenomenon, the number of high affinity $\beta_{2}$ adrenergic binding sites per cell was approximately 3 -fold higher in normal lymphocytes $(869.0 \pm 149.1)$ than in lymphoma cells $(322.8 \pm 77.3 ; \mathrm{P}<0.01)$. 

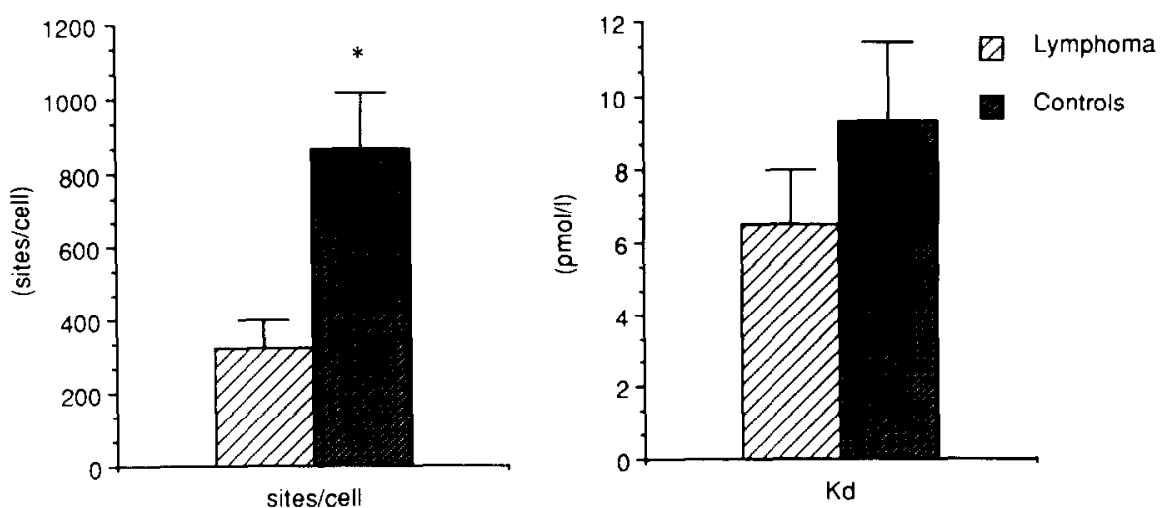

Fig. 2. Density (sites/cell $\left.=B_{\max }\right)$ and equilibrium dissociation constant $\left(K_{d}\right)$ (means $\pm \mathrm{SEM}$ ) of high affinity $\beta_{2}$-adrenergic binding sites of human lymphoma cells $(\mathrm{N}=15)$ and normal lymphocytes $(\mathrm{N}=$ 7). ${ }^{*}$ Difference from lymphoma: $\mathrm{P}<0.01$.

The apparent affinity constant $\left(K_{d}\right)$ exhibited no significant difference (Fig. 2)

\section{Stimulation of $A C$ by different agents}

The basal cAMP accumulation of normal lymphocytes and lymphoma cells showed no difference and did not significantly change within the incubation periods used (10-120 min). The intracellular cAMP accumulation after incubation with $10^{-4} \mathrm{~mol} / \mathrm{L}$ isoproterenol was slightly lower in lymphoma cells $\left(12.0 \pm 2.0 \mathrm{pmol} / 10^{6}\right.$ cells $)$ as compared with normal lymphocytes $\left(18.9 \pm 4.4 \mathrm{pmol} / 10^{6}\right.$ cells; $\left.P=0.06\right)$. At lower concentrations of isoproterenol, the difference in cAMP accumulation between normal and malignant lymphocytes decreased. Cholera toxin increased the intracellular cAMP levels in normal and malignant lymphocytes to the same extent (for all concentrations and incubation periods used); these results, however, showed a considerable interindividual variation, particularly in lymphoma patients as demonstrated by large SEM ranges. Forskolin increased the intracellular cAMP accumulation of lymphoma cells to $22.3 \pm 3.3 \mathrm{pmol} / 10^{6}$ cells (Fig. 3). In normal lymphocytes, this increase was about 8 -fold higher $\left(163.3 \pm 25.9 \mathrm{pmol} / 10^{6}\right.$ cells; $\mathrm{P}<0.01)$. All results were checked for correlations with age of patients and controls without any significant result.

\section{DISCUSSION}

In agreement with previous investigations [18-20] this study shows that the number of high affinity $\beta_{2^{-}}$ adrenergic binding sites is decreased in human low grade lymphoma cells as compared with normal lymphocytes (Figs. 1 and 2). The 3 -fold lower density of $\beta_{2}$-adrenoceptors in malignant B-cells can neither be explained by age differences [41] nor by the elevated B-: T-cell ratio in lymphoma patients as compared with normal donors, because normal Bcells bear more $\beta_{2}$-adrenoceptors than T-cells $[20,42,43]$. The responsiveness of $\mathrm{AC}$ to isoproterenol was only slightly decreased in MNL of lymphoma patients (Fig. 3). The function of the stimulating $G$ protein, $G_{s}$, seemed to be conserved in the malignant $B$-cells as demonstrated by the experiments with cholera toxin (Fig. 3). These results correspond well to similar experiments on CLL lymphocytes using $\mathrm{NaF}$, another stimulator of $\mathrm{G}_{\mathrm{s}}$ $[14,18]$. Finally, the most relevant finding of this study was that the $\mathrm{AC}$ response to forskolin was considerably impaired in the malignant B-cells (Fig. 3).

The results should be interpreted with caution because of the lack of investigations on the effect of forskolin in subpopulations of normal lymphocytes. However, the responsiveness of $\mathrm{AC}$ to a variety of compounds (isoproterenol, NaF, GTP and prostaglandin $\mathrm{E}_{1}$ ) was shown to be higher in $\mathrm{B}$ lymphocytes than in T-lymphocytes [20]. Therefore, it does not seem probable that the decreased AC responsiveness to forskolin in malignant $\mathrm{B}$-cells may be explained by the only difference of $\mathrm{B}$ - and $\mathrm{T}$ cells. With these limitations in mind, it can be concluded from our experiments that the $\beta_{2}$ adrenergic signal transduction in malignant human B-cells seems to be impaired, above all at the AC level. Additionally, the density of $\beta_{2}$-adrenoceptors is decreased. Both phenomena may account for decreased intracellular cAMP levels in these cells $[17,20]$, thereby contributing to their malignant transformation $[13,17,22-28]$.

In this context, Inhorn et al. [28] demonstrated that the restoration of the $\mathrm{AC}$ responsiveness to forskolin, cholera toxin and prostaglandin $E_{1}$ by butyrate was responsible for the antiproliferative effects of these compounds in a murine myeloid cell line. The same authors provided evidence that an imbalance between the inhibitory $G$ protein, $G_{i}$, and the stimulatory $G$ protein, $G_{s}$, might be responsible for the decreased $A C$ activity of this cell line. Alterations of this balance and/or functional changes of $\mathrm{G}_{\mathrm{i}}$ would also help to explain the impairment of the $\mathrm{AC}$ responsiveness to forskolin observed in this study in lymphoma cells. The AC might be permanently inhibited by an absolute or relative increase of the activity of $G_{i}[44]$. Other explanations include the permanent inhibition of $\mathrm{AC}$. by protein 


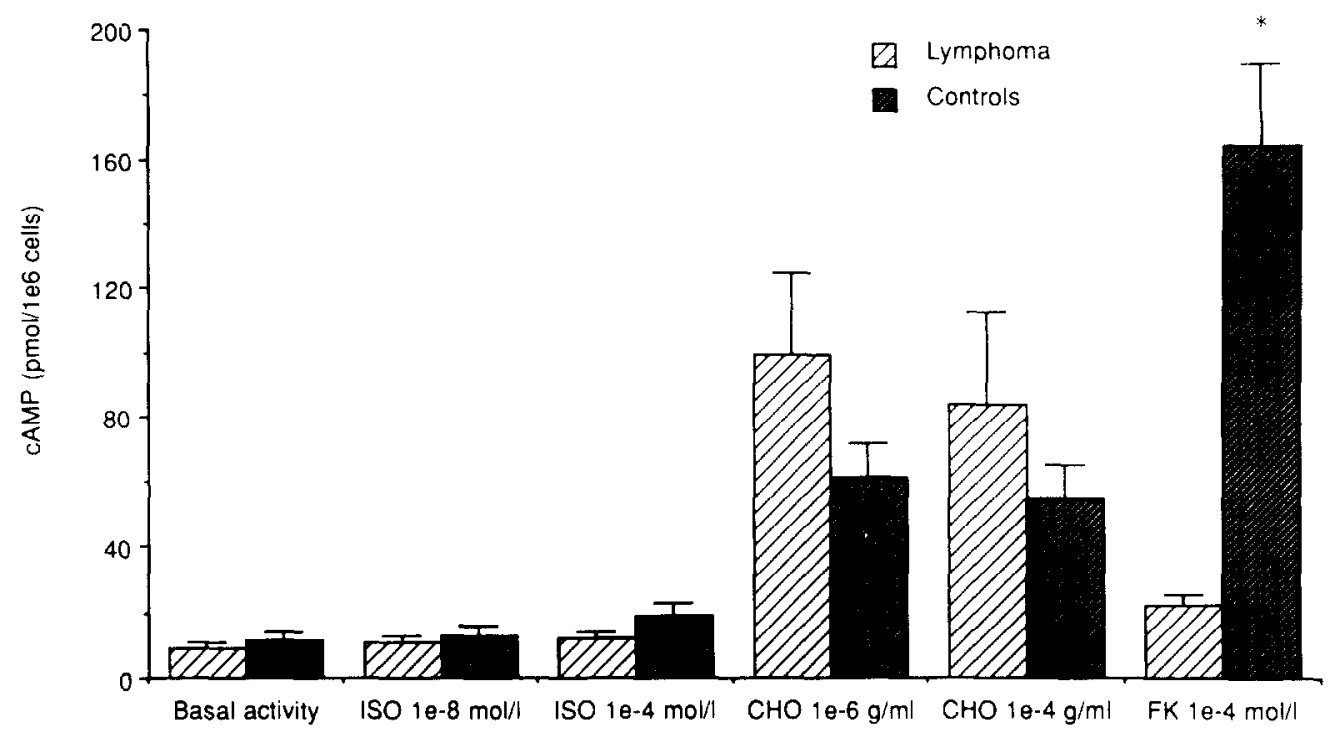

Fig. 3. Stimulation of adenylate cyclase of human lymphoma cells $(N=15)$ and normal lymphocytes $(\mathrm{N}=7)$ by different compounds (ISO $=$ isoproterenol, $\mathrm{CHO}=$ cholera toxin, $\mathrm{FK}=$ forksolin). For isoproterenol and cholera toxin, only two representative experiments are shown, because experiments with different concentrations or incubation periods gave similar results. ${ }^{*}$ Difference from lvmphoma: $\mathrm{P}<0.01$.

kinase $\mathrm{C}$ known to be stimulated by different cytokines and (tumor) growth factors [45], mutations of $\mathrm{AC}$ at its catalytic or regulatory sites, a reduction of $\mathrm{AC}$ synthesis, or an increase of $\mathrm{AC}$ metabolism.

However, increased inhibitory effects on $\mathrm{AC}$, or changes of the catalytic subunit of $\mathrm{AC}$ do not explain by themselves that the stimulation of $\mathrm{AC}$ by isoproterenol and cholera toxin, though taking place upstream in the signal transduction pathway, seems to be less impaired than the direct $\mathrm{AC}$ stimulation with forskolin. One could expect that an impairment of AC should affect the signal transduction pathway to a similar extent at all levels upstream. Our experiments, however, showed no evidence that the AC impairment, as reflected by a significantly reduced responsiveness to forksolin, is necessarily paralleled by a similar decrease of its response to isoproterenol and cholera toxin in lymphoma cells. Therefore, a compensatory mechanism upstream of AC might balance the AC impairment to some extent. In our experiments, the $\beta_{2}$-adrenoceptor number was decreased, and the receptor affinity was not changed in lymphoma cells. Therefore, an increase of the receptor density or affinity does not seem to compensate the $\mathrm{AC}$ impairment. The slightly, but not significantly increased cAMP accumulation in lymphoma cells in response to cholera toxin (Fig. 3) rather supports the hypothesis that the induction of more functional $G_{s}$ molecules could contribute to this compensation. However, this compensation seems to disappear with disease progression and increasing tumor cell proliferation, since the ability of cholera toxin to stimulate lymphocyte $\mathrm{AC}$ was found to decrease significantly with disease progression in CLL and IC patients (Hallek et al., unpublished data).
The most satisfactory explanation derives from the comparison with cell line mutants defective in AC related signal transduction. Those cell lines, particularly $\$ 49$ lymphoma mutants, proved to be powerful tools for studying the interaction between receptors, G proteins and AC [46-48]. Forksolinresistant mutants of $\mathrm{Y} 1$ adrenocortical tumor cells [49] share some common features with our findings in lymphoma cells, and therefore merit close comparison. These mutants had a decreased responsiveness of $\mathrm{AC}$ to forskolin, and, though to a lesser extent, to ACTH (via the receptor) and to $\mathrm{Gpp}(\mathrm{NH}) \mathrm{p}$, a non-hydrolysable GTP analogue. On the contrary, AC was normally stimulated by $\mathrm{NaF}$ (via $G_{9}$ ). Since the cholera toxin-mediated incorporation of $\left[{ }^{32} \mathrm{P}\right] \mathrm{NAD}$ to the $\alpha$ subunit of $\mathrm{G}$, $\left(\alpha_{\mathrm{s}}\right)$ was reduced by $70 \%$, a defect of $\alpha_{\mathrm{s}}$ was suggested. $\alpha_{\mathrm{s}}$ is the regulatory subunit of the $\mathrm{C}_{\mathrm{r}}$ heterotrimer that stimulates the catalytic unit of $\mathrm{AC}$ [44]. It seems to be required for the full stimulation of $\mathrm{AC}$ by forskolin, although forskolin is able to activate $\mathrm{AC}$ in the absence of functional active $\mathrm{G}$. to some extent [47]. The observations on Y1 mutants show similarities to the impairment of $\beta_{2}$-adrenergic signal transduction reported in this study, where the cAMP accumulation was particularly decreased in response to forskolin, and to a lesser extent to isoproterenol (via the receptor) and cholera toxin (via $\mathrm{G}_{\mathrm{s}}$ ) (Fig. 3). They provide a model in which the functionally active subunit of $G_{5}, \alpha_{s}$, rather than the catalytic unit of $\mathrm{AC}$ is altered. These alterations might account for the impairment of the $\beta$-adrenergic signal transduction pathway in human B-cell lymphoma.

These findings await further investigations involving the use of monoclonal antibodies against $\mathrm{AC}$ 
and subunits of $G$ proteins for quantitation by Western blotting, the study of different transmembrane signal pathways inhibiting $\mathrm{AC}$, and the molecular analysis of the subunits of $G_{s}$ and $A C$ in human lymphoma cells. Further studies of the $\beta_{2}$ adrenergic signal transduction in lymphoma cells. with emphasis on the effects of forskolin, are under way. They may improve our understanding of the pathogenesis of lymphoma and help to develop new therapeutic strategies based on modifying the AC activity in lymphoma cells.

Acknowledgements-We thank Dr Bernhard Liebl for stimulating discussions, and Eva M. Lepisto and David C. Ord for critically reading the manuscript. This work was supported by the Sander-Stiftung, grants Nos 820023 and 880201 .

\section{REFERENCES}

1. Brodde OE, Engel G, Hoyer K, Bock KD and Weber $\mathrm{F}$, The $\beta$-adrenergic receptor in human lymphocytes: subclassification by the use of a new radioligand, ( \pm )125iodocyanopindolol. Life Sci 29: 2189-2198, 1981.

2. Gilman AG, G proteins and dual control of adenylate cyclase. Cell 36: 577-579, 1984.

3. Mendelsohn J, Multer MM and Boone RF, Enhanced effects of PGE1 and dibutyryl cyclic AMP upon human lymphocytes in the presence of cortisol. J Clin Invest 52: 2129-2137, 1973.

4. Watson J, The influence of intracellular levels of cyclic nucleotides on cell proliferation and the induction of antibody synthesis. J Exp Med 141: 97-111, 1975.

5. Hadden JW, Hadden EM and Good RA, Adrenergic mechanisms in human lymphocyte metabolism. Biochim Biophys Acta 237: 339-347, 1971.

6. Koopman WJ, Gillis MH and Davis JR, Prevention of MIF activity by agents known to increase cellular cyclic AMP. J Immunol 110: 1609-1614, 1973.

7. Braun $\mathrm{W}$ and Rega MJ, Adenyl cyclase-stimulating catecholamines as modifiers of antibody formation. Immunol Commun 1: 523-532, 1973.

8. Henney CS and Lichtenstein LM. The role of cyclic AMP in the cytolytic activity of lymphocytes. JImmunol 107: 610-612. 1971 .

9. Lies RB and Peters JB, Cyclic AMP inhibition of cytotoxin ("lymphotoxin") elaboration by stimulated lymphocytes. Cell Immunol 8: 332-335, 1973.

10. Strom TB, Deisseroth A, Morganroth J, Carpenter CB and Merill JP, Regulatory role of the cyclic nucleotides in allo-immune lymphocyte mediated cytotoxicity. Effect of imidazole. Transplant Proc 5: 425-427, 1973.

11. Schreiner GF and Unanue ER. The modulation of spontaneous and anti-Ig stimulated motility of lymphocytes by cyclic nucleotide and adrenergic and cholinergic agents. J Immunol 114: 802-805, 1975.

12. MacManus JP, Whitfield JF and Youdale T, Stimulation by epinephrine of adenylcyclase activity, cyclic AMP formation. DNA synthesis and cell proliferation in populations of rat thymic lymphocytes. $J$ Cell Physiol 77: 103-106, 1971

13. Olsson IL, Breitmann TR and Gallo RC, Priming of human myeloid leukemic cell lines HL-60 and U-937 with retinoic acid for differentiation effects of cyclic adenosine $3^{\prime}: 5^{\prime}$-monophosphate-inducing agents and a T-lymphocyte-derived differentiation factor. Cancer Res 42: 3928-3933, 1982.

14. Peracchi M, Maiolo T, Lombardi L, Catena FB and Polli EE, Patterns of cyclic nucleotides in normal and leukaemic human leucocytes. Br J Cancer 41: 360-371, 1980
15. Peracchi M, Lombardi L, Maiolo T, Bamonti-Catena F, Toschi V, Chiorboli O, Mozzana R and Polli EE, Plasma and urine cyclic nucleotide levels in patients with acute and chronic leukemia. Blood 61: 429-434, 1983.

16. Ben-Zvi A, Russell A, Shneyour A and Trainin N, Cyclic-AMP in human lymphocytcs. Levels in acute leukemia and infectious mononucleosis. Eur $J$ Cancer 15: 615-617, 1979.

17. Monahan TM, Marchand NW, Fritz RR and Abell $\mathrm{CW}$, Cyclic adenosine $3^{\prime}: 5^{\prime}$-monophosphate levels and activities of related enzymes in normal and leukemic lymphocytes. Cancer Res 35: 2540-2547, 1975.

18. Sheppard JR, Gormus $\mathrm{K}$ and Moldow CF, Catecholamine hormone receptors are reduced on chronic lymphocytic leukaemic lymphocytes. Nature 269: 693695,1977

19. Bidart JM, Motte P, Bohoun C and Bellet D, Lymphocyte aminergic binding changes in chronic lymphocytic leukaemia. Leukemia Res 5: 443-446, 1981.

20. Paietta $E$ and Schwarzmeier JD, Differences in $\beta$ adrenergic receptor density and adenylate cyclase activity between normal and leukemic leukocytes. Eur $J$ Clin Invest 13: 339-346, 1983.

21. Polgar P, Vera JC and Rutenburg AM, An altered response to cyclic AMP stimulating hormones in intact human leukemic lymphocytes. Proc Soc Exp Biol Med 154: 493-495, 1977.

22. Koeffler HP and Golde DW, Humoral modulation of human acute myelogenous leukemia cell growth in vitro. Cancer Res 40: 1858-1862, 1980.

23. Koeffler HP, Induction of differentiation of human acute myelogenous leukemia cells: therapeutic implications. Blood 62: 707-721, 1983.

24. Chaplinski TJ and Niedel JE, Cyclic nucleotide-induced maturation of human promyelocytic leukemia cells. $J$ Clin Invest 70: 953-964, 1982.

25. Anderson WB, Estival A, Tapiovaara $\mathrm{H}$ and Gopalakrishna R, Altered subecllular distribution of protein kinase C (a phorbol ester receptor). Possible role in tumor promotion and the regulation of cell growth: relationship to changes in adenylate cyclase. Adv Cyclic Nucleotide Protein Phosphoryl Res 19: 287-306, 1985.

26. Levitzki A, Rudick J, Pastan I, Vass WC and Lowy DR. Adenylate cyclase activity of NIH 3T3 cells morphologically transformed by ras genes. FEBS Lett 197: 134-138, 1986.

27. Tarpley WG, Hopkins NK and Gorman RR, Reduced hormone-stimulated adenylate cyclase activity in NIH3 T3 cells expressing the EJ human bladder ras oncogene. Proc Natl Acad Sci USA 83: 3703-3707, 1986.

28. Inhorn L, Fleming JW, Klingberg D, Gabig TG and Boswell HS, Resotration of adenylate cyclase responsiveness in murine myeloid leukemia permits inhibition of proliferation by hormone. Butyrate augments catalytic activity of adenylate cyclase. Blood 71: 1003-1011, 1988.

29. Pines M, Ashkenazi A, Cohen-Chapnik N, Binder L and Gertler $\mathrm{A}$, Inhibition of the proliferation of $\mathrm{Nb2}$ cells by femtomolar concentrations of cholera toxin and partial reversal of the effect by 12 - $O$-tetradecanoylphorbol-13-acetate. J Cell Biochem 37: 119-129, 1988.

30. Blomhoff HK, Smeland EB, Beiske K, Blomhoff R, Ruud E, Bjøro T, Pfeifer-Ohlsson S, Watt R, Funderud S, Godal T and Ohlsson R, Cyclic AMP-mediated suppression of normal and neoplastic $B$ cell proliferation is associated with regulation of myc and Ha-ras protooncogenes. J Cell Physiol 131: 426-433, 1987.

31. Phipps RP, Lee D, Schad V and Warner GL, E-series of prostaglandins are potent growth inhibitors for some B lymphomas. Eur J Immunol 19: 995-1001, 1989. 
32. Gérard-Marchant R, Hamlin I, Rilke F, Stansfeld AM and van Unnik JAM, Classification of non-Hodgkin's lymphomas. Lancet ii: 406-408, 1974.

33. Binet JL, Catovsky D, Chandra P, Dighiero G, Montserrat E, Rai KR and Sawitsky A, Chronic lymphocytic leukemia: proposals for a revised prognostic staging system. Br J Haematol 8: 365-367, 1981 .

34. Carbone PP, Kaplan HS, Musshoff K, Smithers DW and Tubiana M, Report of the Committee on Hodgkin's disease staging classification. Cancer Res 31: 18601861,1971

35. Anhäupl T, Liebl B and Remien J. Kinetic and equilibrium studies of $(-)^{125}$ iodocyanopindolol binding to $\beta$-adrenoceptors on human lymphocytes: evidence for the existence of two classes of binding sites. $J$ Receptor Res 8: 47-57, 1988.

36. Böyum A, Isolation of leukocytes from human blood. Further observations. Methylcellulose, dextran, and ficoll as erythrocyte-aggregating agents. Scand J Clin Invest 21 (Suppl 97): 77+89, 1968

37. Haen E, Liebl B, Lederer T and Pliska V, Revised radioreceptor assay for $\beta_{2}$-adrenoceptors expressed on peripheral mononuclear leukocytes. $J$ Receptor Res, in press.

38. Sandnes D, Waelgaard J and Jacobsen S, Modes of determining $\beta$-adrenoceptor number in human mononuclcar leukocytcs. Pharmacol Toxicol 61: 265$270,1987$.

39. Scatchard G, The attractions of small molecules and ions. Ann NY Acad Sci 51: 660-672, 1949.

40. Salomon Y, Londos $C$ and Rodbell M, A highly sensitive adenylate cyclase assay. Anal Biochem 58: 541-548, 1974
41. Halper JP, Mann JJ, Weksler ME, Bilezikian JP, Sweeney JA, Brown JP and Golbourne T, Beta adrenergic receptors and cyclic AMP levels in intact human lymphocytes: effects of age and gender. Life Sci 35: 855-863, 1984.

42. Krawietz W, Werdan K, Schober M, Erdmann E, Rindfleisch GE and Hannig K, Different numbers of $\beta$-receptors in human lymphocyte subpopulations. Biochem Pharmacol 31: 133-136, 1982.

43. Landmann RMA, Bürgisser $E$, Wesp $M$ and Bühler FR, Beta-adrenergic receptors are different in subpopulations of human circulating lymphocytes. $J$ Receptor Res 4: 37-50, 1984

44. Neer EF and Clapham DE, Koles of G protein subunits in transmembrane signalling. Nature 333: 129-134, 1988.

45. Nishizuka $Y$, Studies and perspectives of protein kinase C. Science 233: 305-312, 1986.

46. Johnson GL, Kaslow HR, Farfel $Z$ and Bourne HR, Genetic analysis of hormone-sensitive adenylatecyclase. Adv Cyclic Nucleotide Res 13: 1-33, 1980.

47. Jakobs KH, Aktories $\mathrm{K}$ and Schultz G, A nucleotide regulatory site for somatostatin inhibition of adenylate cyclase in S49 lymphoma cells. Nature 303: 177-178, 1983.

48. Insel PA, Motulsky HJ and Mahan LC, Regulation of cyclic AMP accumulation in lymphoid cells. Proc Soc Exp Biol Med 179: 472-478, 1985.

49. Schimmer BP, Tsao J. Borenstein R and Endrenyi L. Forskolin-resistant Y1 mutants harbor defects associated with the guanyl nucleotide-binding regulatory protein, $\mathrm{G}_{\mathrm{s}}$. J Biol Chem 262: 15521-15526, 1987. 